\title{
Transformation of Scientific Atheism in the Late USSR and Post-Soviet Russia
}

\author{
Valery V. Farkhitdinov \\ Academy of Tourism and International Relations \\ 17 Marata Str., Ekaterinburg, 620034, Russia
}

Received 08.11.2018, received in revised form 29.04.2019, accepted 07.05.2019

\begin{abstract}
The subject of the research is the destiny of scientific atheism in the transformation of the atheism-based state ideology of Russia. The objective of the research is the analysis of scientific atheism in the late USSR and Russia in the post-Soviet Russia.

The article encompasses descriptive, comparative, retrospective analysis methods etc. The field of applying research results is social sciences and humanities. The research concludes that the disputes between atheists and believers heated up in the first two decades of the $21^{\text {st }}$ century, even though conceptually the problem seemed settled. The dispute of atheists and believers belongs more to the conceptual framework, where the parties struggle to clarify the terms of faith and atheism. The argument is aggravated by the latest intrusion of scientific research into the "purely religious matters" and the frequent operation of such religious terms as avatar, god particle, immortality, soul etc. It complicates the demarcation of scientific and religious world outlooks.
\end{abstract}

Keywords: scientific atheism, state ideology, discussion, faith, religion.

Research area: philosophy.

Citation: Farkhitdinov, V.V. (2019). Transformation of scientific atheism in the late USSR and Post-Soviet Russia. J. Sib. Fed. Univ. Humanit. soc. sci., 12(5), 780-790. DOI: 10.17516/19971370-0422.

The topicality of the article is determined by the recently aggravating everlasting disputes of the religious and scientific outlook followers. Unfortunately, disputes between atheists and believers go far beyond academic discussions and manifest themselves in socially relevant actions. Those are dancing in the church, cutting down crosses and desecration of graves, religious terrorism etc. Perhaps, the aggravating opposition between atheists and believers is connected to the resurgence of religion that is currently in process in our society.

(c) Siberian Federal University. All rights reserved

* Corresponding author E-mail address: uralinsttur@yandex.ru

This work is licensed under a Creative Commons Attribution-NonCommercial 4.0 International License (CC BY-NC 4.0). 
In this regard, Peter Berger came up with the term desecularization, as a process of resurgence of religion (Berger, 2012: 9). A. Shishkov uses different terms, such as asecularization, post-secular, speaking of the development of desecularization in the post-Soviet Russia (Shishkov, 2012: 170).

The resurgence of the religious world outlook provokes atheists to react. That is the protest of the so-called scientific atheists, expressed in the numerous publications and scientific researches.

All that causes the growing interest to the destiny of scientific atheism in the $21^{\text {st }}$ century, to its development and transformation in the late USSR and post-Soviet Russia. It is related to the fact that, besides being a tool of communistic propaganda and ideology, it attempted to become the underlying belief for the future society. It claimed being global and even "cosmic". Let us recall the vision of the future presented by the Soviet science fiction writers, especially I. Efremov, the early Strugatsky Brothers etc. They definitely associated scientific atheism with the progress of man and the humankind in general.

The collapse of the Soviet regime and communistic ideology led to resurgence of different religions and religious world outlooks.

Atheism it the outlook system of those who deny existence of deities or any other supernatural powers, excarnate spiritual beings.

In the broadest sense, atheism is understood as the absence of belief in the existence of deities. Less broadly, atheism is the rejection of belief that any deities exist.

Atheism is contrasted with theism, which, in its most general form, is the belief that at least one deity exists.

Atheism may be interpreted as rejection of existence of any supernatural powers: deities, spirits, demons, angels, afterlife etc.

As a rule, atheism is opposed to monotheism, as it claims that god does not exist. Atheism should be distinguished from agnosticism, which does not directly reject the existence or absence of deity.

There are different classifications of atheism.

In the $20^{\text {th }}$ century, Paul Kurtz came up with the terms of ignosticism and igtheism. Ignosticism or igtheism is the idea that any theological position makes unjustified and contradictory assumptions about the concept and attributes of deities (Kurtz, 2005: 190).

The concept of atheism, close to its modern meaning, appeared in the Renaissance period in Europe. It was used for the description of one's convictions in the $18^{\text {th }}$ century, meaning rejection of belief in the monotheistic Judeo-Christian god. 
The Enlightenment marked the emergence of atheism on a scientific basis. "The System of Nature" by Baron d'Holbach became the "bible of atheism".

Atheism criticized religion from various positions. One of the arguments was the unclear anthropomorphic image of god in the Abrahamic religions. Another argument was the absence of clear proofs of the existence of god. B. Russel denied the first proof of god by Thomas Aquinas (Argument from Efficient Causes) and the cosmological proof of Aristotle (the Unmoved Mover) (Kurtz, 2005: 190).

An important argument of atheists is the vagueness of deity as a term. Even Bertrand Russell said that he did not deny the term of a deity since he did not know what it actually meant (Russell, 1986).

The logical positivism arguments focus on the meaningless of the general god existence statement. To the utterance saying "god exists", the logical positivists normally reply: "What do you mean by that?" (Blinnikov, 2010: 170).

S. Freud operated psychological arguments claiming that religion satisfies the natural emotional needs of a person. Freud asserted that the essence of religion is the helplessness and fear of man in the face of mighty natural powers.

To a great extent, scientific atheism developed due to the efforts of L. Feuerbach, K. Marx, and F. Engels.

Ludwig Feuerbach claimed that man made god in his image (Oyzerman, 1990: 155).

Marx and Engels understood religion as a form of reflecting reality and attempted to justify its emergence and existence with the material conditions of life of a society.

In the Introduction to "Critique of Hegel's Philosophy of Right", Marx for the first time formulated the main principles of scientific atheism. K. Marx asserted the activeness of man in the religion development questions. It is not religion that creates man, this is man who creates religion; "religion is, indeed, the self-consciousness and self-esteem of man who has either not yet won through to himself, or has already lost himself again. But man is no abstract being squatting outside the world. $<\ldots>$ This state and this society produce religion, $<\ldots>$ they are an inverted world. Religion is the general theory of this world..." According to Marx, "Religion is the sign of the oppressed creature, the heart of a heartless world, and the soul of soulless conditions. It is the opium of the people" (Marx, 1955: 219-368).

The main principles of the Marxist atheism are listed below:

1. The emergence of religion was caused by the idea of dependence of man on the powers of nature, impotence to change the conditions of his life, and the fear of death. 
2. Religion is used by the exploiters to excuse exploitation of man by another man.

3. Struggle against religion is an integral part of struggle against the unjust social and economic order established by the ruling classes.

4. Abolishment of religion will release the creative potential of the exploited majority for the struggle for the living conditions, appropriate for a working man (Religiia, 1983: 383).

In the USSR, scientific atheism was a part of the state ideology. The term of "scientific atheism" itself got widely spread in the Soviet Union in the middle of the $20^{\text {th }}$ century. It was formulated in Decree of the CPSU Central Committee "On Major Drawbacks in the Scientific and Atheist Propaganda among the Population". In 1959, the subject titled "Basics of Scientific Communism" was introduced into the Soviet Union higher education curriculum. After, the Institute of Scientific Atheism was established.

Therefore, atheism became a popular term in the $19-20^{\text {th }}$ centuries and served as a basis for the development of a new world outlook system. V.G. Gendel (Gendel, 1975: 152), Yu. V. Krianev (Krianev, 1961) regarded atheism only as "criticism of religious consciousness", presenting atheism as dependent on religion. Others, such as N.A. Pashkov (Pashkov, 1974), I. N. Iablokov (Iablokov, 1971), M. M. Grigor'ian (Grigor'ian, 1974) claimed that scientific atheism should not be limited to criticism of religion; it also carries some constructive ideas, such as the postulate on the priority and value of personality, its life in this world etc.

Scientific atheism is based upon scientific cognition methods. In its turn, scientific cognition method is based on deducing regular patterns from experience, logical structures, empiric validation of theoretical statements and the principle of sufficient reason. And even though scientific world outlook as such happened to be criticized (Neo-Positivism, Post-Positivism), USSR had been holding firmly to the scientific approach to atheism.

It is well-known that atheistic propaganda was very active in the Soviet period. Religious world outlook was presented as an obstacle to breeding a new type of man. According to Soviet atheists, religious outlook assumes submission to the reality, to the incomprehensible power of nature created by superior spirits (deity). However, communistic ideology that reigned in the USSR spoke about the possibility of cognizing the world with the human mind, asserted the need to rebel against the power of nature. "Man! That has a proud sound!" is one of the key phrases of the Soviet atheism. There is another phrase quoted from the book by S. Snegov, which embraced the entire message of the Soviet atheism: "Men like Gods!" 
The analysis of the Soviet atheistic researches demonstrated that the ideas of atheism and religion began to gradually transform in the last third of the $20^{\text {th }}$ century and continued changing after the collapse of the socialistic system.

If in the earlier publications (such as in "The Atheistic Readings" journal) only the criticism of religion dominated, in the 1980-s there appeared a large number of articles that, though critically, but were intended to introduce various religions to the Soviet people. In the later publications, the religious world outlook co-existed with a lively interest for various religious issues (Gaev, 1986: 25).

Atheists could not but admit that religion is impossible to eliminate, that people have always been attracted to the religious questions. It is proved by the following issues of "The Atheistic Readings". In the 1980-s, atheism switched to defence: besides pure propaganda, many researches of religious topics were published (Shakhnovich, 1987).

Despite being studied within the history of religion and the religiousatheistic situation with sociological methods, in the Soviet years scientific atheism was generally considered to be a philosophic science, developing public opinion on individual questions and influencing the world outlook of the nation as a whole, since an important place in its structure was occupied by philosophy of religion.

In the first post-Soviet years, the term of scientific atheism itself started to retract to the periphery of social life and scientific attention. In the first years after the collapse of the socialistic state, the society and the scientific community became overwheled by various religious questions. Religion became fashion. All religions and confessions in Russia were revived. Gradually, religious organizations began to gain influence, supported by the state and private sponsors.

In this regard, theorists directed their attention to the religious outlook resurgence processes. Particularly, in 1999 the collection of articles with the symptomatic title "The Desecularization of the World" edited by Peter Berger was published. Later, Jürgen Habermas introduced the expression of post-secular society (Habermas, 2008), and Gustav Schneider came up with the term of post-atheistic society (Schneider).

First of all, the expectations of the secularization supporters turned out to be overrated. The seemingly strong argument on the existence of a direct relation between modernization and secularization of society (scientific and technical progress, restriction of social significance of the church institutions, increase in the general well- 
being of the population and confidence about the future) did not deliver on all of its promises.

The religion did not disappear, but remained relevant in the lifestyle, culture and politics not only of the Western secularized society, but the entire humankind as a whole.

As J. Habermas writes that, riding on the wave of the rightful criticism of the narrowed, Europe-centred approach, there appeared a thesis on the end of the secularization theory. For a long time, the USA, with their permanently strong and active religious communities and unchanging large number of believers, holding the leading positions in modernization, were considered to be a rare exception from the general secularization tendency. However, if we take a look at other cultures and regions of the world from an angle broadened to the global scale, the USA will look more regular. Under this reviewed angle, the European model, which, with its Western rationalism was intended to be an example for the rest of the world, looks like a special way of development (Habermas, 2008).

Compared to the modern, in the post-modern situation religion finds itself in a new situation with the opposition of faith and mind, religion and science, as well as the conflict of old religions with the new quasi-religions, like positivism, Marxism, progressism. In the post-modern culture, the secular gets mixed and intertwined with the religious. Post-secular society assumes communication, and a search for a compromise between the secular and the religious. According to Habermas, religion should not reject, but accept secularism and its achievements as a historical fact, and come to terms with it. While the secularized society, in its turn, should admit that such "coming-to-terms" religions also have a right to exist.

In our country, desecularization processes were peaceful and historically fast.

All around the country, churches and religious organizations resumed their activity; a great number of religious publications appeared. Scientific atheism issues somehow receded to the background. Many of the previously active atheists, former party and Komsomol activists began preaching these or those religions.

In the 2000-s, desecularization processes continued. Desecularization of the Russian society was generally following the ideas formulated by Jurgen Habermas. There were attempts of reconciliation of believers and non-believers; even some statements on the similarity between the communistic and Christian ideas were made.

Contemporary Russian communists criticize religion at the world outlook level, though accept some tactical unions. For example, at the denoted website, 
V.S. Markov expressed the idea that if Orthodox Christianity forms the core of the Russian national spirit, it should be supported to oppose the materialistic aggression of the West.

There are some discussions on the similarity between certain provisions of Islam and communism. This is the way A. Malashenko formulates the question in his article, published on the CenterAsia website: "Is Islam Today's Communism?"

Similar thoughts are found in the book "Islam After Communism. Religion and Politics in Central Asia" by Adib Khalid (Adib Khalid, 2010).

Therefore, we may conclude that desecularization processes in the post-Soviet Russia did not cause a radical dismantlement of the atheistic world outlook. These processes were framed by the tolerant relationships between believers and nonbelievers, and the dialogue they built.

The dialogs between atheists and believers can be found on such websites as www.k-istine.ru, forum-hristian.ru, cirota.ru etc. Those are the articles by Archimandrite Epiphanius Theodoropoulos "Dialogue with an Atheist", Priest Vitaly Babichev "Dialogue with an Atheist", Maxim Stepanenko "Two Faces of Atheism. Better Being With the "Fictious" God and Sinful Popes" etc.

The disputes between believers and non-believers may be really fierce, and it is not seldom when the believers themselves come up with criticism of the excessively fervent representatives of Orthodox Christianity, who do not always understand the essence of Christianity and its ideals. It can be seen, for example, in the article by Sergei Khudiev "Where Would This Huge Brain Go: Why Did Believers Happen to Be Sillier Than Atheists". The atheists themselves can also criticize atheistic world outlook, as seen in the article by Boris Kollender "Atheist Against Atheism or Minuses of Atheism”.

Indeed, some hard criticism could not be avoided. Particularly, the famous priest Andrei Kuraev was quite critical about communism and materialism. It can be found in his article "The Occult Communism". Similar criticism is expressed by Innokenty Kireev in his article "The Contradictions of Atheism", Gustav Schneider "From Atheism to Paganism", Archipresbyter Alexander Shmeman "Subjugation of Man by Atheistic Society", Grigory Kertman "The Atheistic Minority" etc.

Atheists were also criticized by the famous Islamic activists of Russia Geydar Dzhemal in his books "The Revolution of the Prophets", "Exemption of Islam", "Islamic Intellectual Initiative in the $20^{\text {th }}$ Century" etc.

This way, the said period (1990-s) in Russia can be referred to as the period of desecularization, and its society can be called post-secular. 
In 1999 , only $5 \%$ of respondents claimed to be atheists.

Little by little, the statements of the post-Soviet atheists got more elegant and consistent. It was observed in the late 1990-s. At the same time, a new property of Russian atheism manifested itself: it found a virtual shape, developing, first of all, in the sphere of the Internet, influencing, first of all, the minds of the young people who refuse to accept any traditional religions.

In 1996, the fist and still operating atheistic Internet project was started in Novosibirsk; it was titled "The Atheistic Site", or "A-Site", supported by the local educational network of Novosibirsk.

Among the serious atheistic Internet portals, there is the "Scientific Atheism" website created by A. Viazovsky and M. Ieliseykin, committed to more scientific forms of discussion and presentation.

In June 2001, A-Site published the finalized text of "The Atheism Manifesto", that declares that "Atheism is not a mere disbelief in god", but it is a world outlook that encompasses scientific, moral, and social grounds for the denial of existence of deity and the philosophy of life without deity. Atheism is based on recognition of the natural world surrounding man as the only and the sustainable one, and consideration of religion and deities as creations of man himself. Atheism is based on the naturalistic cognition of the world, opposing acquired knowledge to belief.

Therefore, resurgence of atheism in our country rather sticks to disputing with believers, proving the thesis that atheism is not an independent world outlook; it is always directed to criticism of the religious one. There are very few atheistic websites and publications with no anti-religious propaganda or anti-religious slogans.

The disputes of believers and non-believers are mostly limited to the discussions of the moral and ethical aspects of society. The believers claim that atheism analogizes people to animals, since, without any high meaning, without recognition of the absolute truth of good and love, man is nothing but a highly developed animal. Non-believers argue that only belief in the human power may retain the dignity of man. While religions, especially the Abrahamic ones, assert the vanity of man, slowing down the development of the humankind.

The gnoseological and ontological arguments are quite rare and mostly occur in the academic environment. However, all of them are focused around atheism, and hardly ever around scientific atheism. In fact, today's atheists tend to repeat the arguments of the scientific atheists of the $19-20^{\text {th }}$ centuries, proving the absence of supernatural powers and justifying this world with the scientific world outlook. 
The term of atheism itself was studied in the works by D. V. Pivovarov.

Among his publications on atheistic and religious outlooks, there are the following: "Faith and Knowledge in Religion and Science", "History and Philosophy of Religion", "Soul and Faith", "Language of Religion" etc. According to the listed publications, D. V. Pivovarov is not a supporter of scientific atheism. For instance, in "Philosophy of Religion" he writes that the concept of atheism in its terminology and thinking is greatly similar to the religious doctrine. He suggests that abstract atheism does not exist at all. Any non-religious atheism is tied to the religion is criticizes.

This way, we may suppose that the term of scientific atheism is a product of the Soviet period relied upon its materialistic world outlook and the dialectic materialism theory of K. Marx, F. Engels, V. Lenin etc.

At least, today this term is pushed to the periphery of the social and scientific life, giving way to atheism and humanism.

\section{References}

Adib Khalid (2010). Islam posle kommunizma. Religiia i politika v Tsentral'noy Azii [Islam After Communism. Religion and Politics in Central Asia], translated by A. Bogdanov. Moscow: Novoe literaturnoe obozrenie, 304 p.

Berger, P. (2012). Fal'sifitsirovannaia sekuliarizatsiia [Secularization Falsified]. In: Gosudarstvo, religiia, tserkov' [State, Religion, Church], 2, 8-19.

Blinnikov. L.V. (2010). Kratky slovar' filosofskikh personaliy [Shorter Dictionary of Philosophic Personalities], Novosibirsk. 432 p.

Gaev, G.I. (1986). Khristianstvo i iazycheskaia kul'tura [Christianity and Pagan Culture]. In: Ateisticheskie chteniia [The Atheistic Readings], Issue 16, 25.

Gendel, V.G. (1975). K voprosu o predmete ateizma [To the Question on the Subject of Atheism]. In: Filosofskie nauki [Philosophic Sciences], 1, 152-153.

Grigor'ian, M.M. (1974). Kurs lektsiy po istorii ateizma [Lectures on History of Atheism]. Edition two, rev. Moscow: Mysl'. P. 10.

Habermas, J. (2008). Postsekuliarnoe obshchestvo - chto eto? [What is the Meaning of Post-Secular Society?]. In: Rossiyskaia filosofskaia gazeta [Russian Philosophical Newspaper], 4 (18) April 2008; 5 (19) May 2008.

Iablokov, I.N. (1971). O nauchnoy interpretatsii dinamiki psikhologicheskikh sostoianiy veruiushchikh $\mathrm{v}$ molitve i pokaianii [On Scientific Interpretation of Dynamics of Psychological States of Believers in Prayer and Penance]. In: Voprosy nauchnogo ateizma [Questions of Scientific Atheism]. Issue 2. Moscow. 
Krianev, Iu.V. (1961). Protivopolozhnost' khristianskoy ideologii i nauchnogo kommunizma [Opposition of Christian Ideology and Scientific Communism]. Moscow.

Kurtz, P. (2005). Igteizm [Igteism]. In: Novyy skeptitsizm. Issledovanie i nadezhnoe znanie [New Scepticism. Research and New Knowledge], translated from English and foreword by Kuvakin, V.A. Moscow: Nauka P. 190. 360 p.

Marx, K. (1955). K kritike gegelevskoy filosofii prava, 1844 [Critique of Hegel's Philosophy of Right, 1844]. In: Marx K., Engels F. Sochineniia [Collected Works]. 1 (1), 219-368.

Nikonov, A. (2004). Apgreyd obez'iany. Bol'shaia istoriia malen'koy singuliarnosti [Upgraded Ape. Big Story of Small Singularity], Moscow: ENAS.

Oyzerman, T.I. (1990). Liudvig Feyerbakh o religii i putiakh chelovecheskoy emansipatsii [Ludwig Feuerbach on Religion and Human Emancipation]. In: Obshchestvennye nauki [Social Sciences], 3, 54-163.

Pashkov, N.A. (1974). Aktual'nye problemy nauchno-ateisticheskikh issledovaniy [Current Problems of Scientific Atheism Research]. In: Filosofskie nauki [Philosophical Sciences], 1, 126-138.

Religiia [Religion] (1983). In: Ateisticheskiy slovar' [Atheistic Dictionary] / Abdusamedov, A.I., Aleynik, R.M., Alieva, B.A. et al, edited by M.P. Novikov, Edition 2, rev. and corr. Moscow: Politizdat. P. 383-384.

Russell, B. (1986). Sushchestvovanie boga [Existence of God]. In: Iakovlev, A. A. Predislovie k publikatsii "Disputa o sushchestvovanii boga" [Introduction to the Article "Dispute on Existence of God”], Voprosy filosofii [Questions of Philosophy] Available at: http://magister.konvent.ru

Schneider, G. Ot ateizma k iazychestvu [From Atheism to Paganism]. Available at: http://www.k-istine.ru

Shakhnovich, M.I. (1987). Protiv sotsial'nogo i dukhovnogo rabstva [Against Social and Spiritual Slavery]. In: Ateisticheskie chteniia [The Atheistic Readings]. Moscow: Politizdat, 3-33.

Shishkov, A. (2012). Nekotorye aspekty desekuliarizatsii v postsovetskoy Rossii [Some Aspects of Desecularization in the Post-Soviet Russia]. In: Gosudarstvo, religiia, tserkov'v Rossii i za rubezhom [State, Religion, Church in Russia and Abroad], 2, $165-175$. 


\title{
Трансформация научного атеизма \\ в позднем СССР и постсоветской России
}

В.В. Фархитдинов

Академия туризма и международных отношений Россия, 620034, Екатеринбург, ул. Марата, 17

\begin{abstract}
Предметом научного исследования выступает судьба научного атеизма в условиях трансформации основанной на нем государственной идеологии в России. Целью изучения является анализ трансформации научного атеизма в позднем СССР и постсоветской России.

В статье использовались дескриптивный метод, метод сравнения, ретроспективный анализ и ряд других. Область применения результатов исследования сочииально-гуманитарные науки. В заключение были сделаны выводы о том, что споры атеистов и верующих стали разгораться с новой силой в первые два десятилетия XXI века, несмотря на то что на концептуальном уровне, казалось бы, проблематика оказалась исчерпанной. Полемика атеистов и верующих все больше смещзается в сферу понятийного аппарата, когда стороны пытаются прояснить смысл понятий «вера» и «атеизм». Споры обостряются еще и в связи с тем, что научные исследования в последнее время все чаще вторгаются в "чисто религиозные вопросыл» и нередко используют религиозные термины: «аватар», «частица Бога», «бессмертие», «душа» и др. Это усложняет возможность демаркации научного и религиозного мировоззрения.
\end{abstract}

Ключевые слова: научный атеизм, государственная идеология, дискуссия, вера, религия. Научная специальность: 09.00.00 - философские науки. 